Liliia Khomenko,

Sumy State University, Ukraine

ORCID ID, 0000-0001-5690-1105

email:I.khomenko@biem.sumdu.edu.ua

Anna Rosokhata,

Ph.D., Sumy State University, Ukraine

(iD) ORCID ID, 0000-0001-6944-1515

email:a.rosokhata@gmail.com

Adam Jasnikowski,

Director, Fundacja EUROWEEK, Poland

(i) ORCID ID, 0000-0002-5695-2364

email: adamjasnikowski1@gmail.com

Correspondence author: I.khomenko@biem.sumdu.edu.ua

\title{
ANALYSIS OF TERRITORIES MARKETING ACTIVITIES AMONG SMALL AND MEDIUM BUSINESS: A BIBLIOMETRIC ANALYSIS
}

Abstract. The article summarizes the arguments and counterarguments in the scientific discussion on place marketing. The study's main purpose is to understand the nature and features of existing research on marketing areas to determine the direction of future research for both scientists and practitioners. Systematization of literature sources and approaches to solving the problem of marketing areas suggests that many studies in this area require a synthesis of existing research. The urgency of solving this scientific problem is that although the use of marketing in public administration has intensified in recent years, there are many problems in this area. The research of place marketing was carried out in the following logical sequence: determination of the impact of the authors, journals, and articles on territorial marketing, keyword analysis, identification of marketing clusters, visualization of scientific literature on place marketing. The study covers 1970-2021. The research object is 1611 relevant publications published in various scientific sources. The most influential journals were found to be the Journal of Business Research, Tourism Management and Marketing Theory. The most cited authors were Kavaratzis M. and Warnaby G. Most of the articles have been published by researchers from the USA, England, Italy, Canada, the Netherlands, Germany, Australia, and France. Eight key clusters were identified in the marketing of territories: politics, tourism, model, identity, place branding, residents, framework, city brand. In the last five years, most research has been devoted to placing brands, destination marketing, geographies, politics, culture, place branding, identity, tourism, involvement, governance, impact, smart city, loyalty, community. Areas of future research could include destination brand, technology, regeneration, legitimacy, experiences, word-of-mouth, attitude, reflections, memory, inequity of cities, inclusive place branding, brand equity, place attachment, place identity, and others. It is also recommended to focus on city-twinning, sister city, municipal cooperation. The study results could be helpful for companies involved in developing the brand of territories, local authorities for the development of place marketing, and scientists researching place marketing.

Keywords: bibliometric analysis, marketing management, marketing tools, place marketing, place branding, small and medium enterprises, territorial marketing, tourism infrastructure, partnership for sustainable development, city branding.

Introduction. Place marketing (territorial marketing, marketing of territory) plays an essential role in increasing business activity in the region. It promotes the development of the local community, attracting financial and labor resources. Although marketing in public administration has intensified in recent years, there are many problems in this area, such as the lack of general understanding, necessity, and practice

Cite as: Khomenko, L., Rosokhata, A., \& Jasnikowski, A. (2021). Analysis of Territories Marketing Activities Among Small and Medium Business: A Bibliometric Analysis. Marketing and Management of Innovations, 4, 184195. http://doi.org/10.21272/mmi.2021.4-14 
of marketing in the management of territories. There are also problems with the effectiveness of local government policies in regional development, aimed at increasing the competitiveness of territories, developing territorial development plans, and attracting investment in the regions. There are many scientific studies in this field, particularly on place branding, place marketing, image, destinations, models, impact, involvement, politics, management (Liubchak et al., 2021), tourism, cities, and others. In turn, many publications focused on marketing management in small and medium businesses. Apospori $\mathrm{E}$., Zografos K.G., Magrizos S., Danis W., Chiaburu D., Lyles M., Odoom R., Spence M., Essoussi L.H. have worked on these topics. Moreover, the number of publications on place marketing increases every year, indicating the relevance of these issues (Us et al., 2020).

This study focuses on bibliometric analysis of the literature on the marketing of territories. It allows analyzing many studies on selected topics more objectively and quantitatively (Khomenko et al., 2020; Rosokhata et al., 2021).

This paper examines scientific publications on the marketing of territories, analyzes the content of publications, cluster analysis (Khomenko et al., 2021), and visualization of the literature, which helps to illustrate the scope of research.

The main purpose of this study is to understand the essence and features of existing research on the marketing of territories to determine the direction of future research for both scientists and practitioners.

To achieve this goal, this study:

- determined the influence of authors, journals, articles on the marketing of territories,

- identified existing place marketing clusters,

- analyzed key aspects and presented the visualization of scientific literature on the place marketing;

- predicted the directions of future research for scientists and practitioners.

The document begins with an introduction, followed by brief descriptions of available review publications on the subject. The following section discusses key journals, authors studying place marketing. It is followed by analyzing citations and identifying the most influential publications and authors. The following section describes the results of hierarchical cluster and evolutionary keyword analysis to explain better existing and predict future research directions. The last section contains recommendations for future research.

As a result of the analysis of scientific publications according to the Web of Science database, 1611 publications were selected for the following queries: place marketing OR place branding OR territorial marketing (in the headings). Figure 1 presents the dynamics of publications by year.

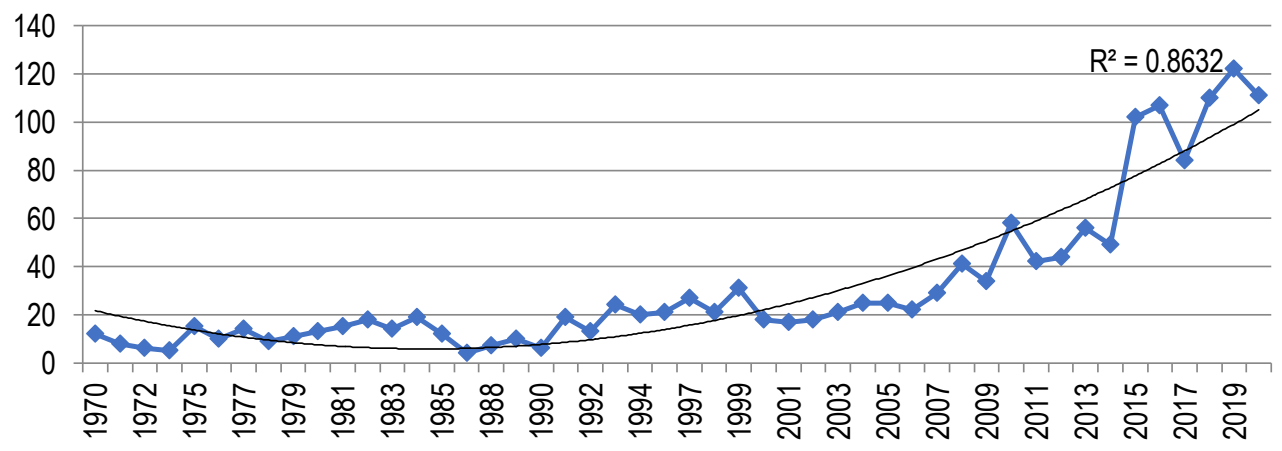

Figure 1. Dynamics of publications by years

Sources: developed by the authors based on the Web of Science database. 
Although the first publications appeared in the 1070s, their number has multiplied alone in the last 10 years (Figure 1). It indicates the recent awareness of many about the need to promote brands in the territories. At the same time, 35\% of all works were published during 2016-2021. However, during 19701999 only $25 \%$ of the articles were published.

These studies were conducted in more than 100 areas of research. More than $70 \%$ of publications belong to one of the research areas: business economics, social sciences, geography, environmental sciences ecology, urban studies, and public administration.

The authors of 82 countries researched the marketing of territories. Scientists from the USA and England have published most studies. Also, more than 50 studies have been published by scientists from Italy, Canada, the Netherlands, Germany, Australia, and France.

Literature Review. During this study, 30 review articles were found on the marketing of territories. The following describes only the most relevant studies with at least one citation.

Madsen (1992) conducted a detailed review of Liverpool's promotional materials and interviews with key officials about Liverpool's brand development. Kiralova (1995) drew attention to the inevitability and preconditions of marketing a tourist place, especially Slovak centers, cities, and villages. The author emphasized that the application of proven marketing principles in a tourist place and the further development of the concept of tourist marketing at the center, city, or village levels, respectively, play an essential role in the success of a tourist place.

Metaxas (2009) studied the processes of place marketing and strategic planning on the example of Malta as a competitive tourist destination. He identified the main components that ensured the effectiveness of marketing and strategic planning and presented the process of repositioning the image of Malta in the international tourism market.

Cleave and Arku (2017) systematized what is known about attempts to quantify the impact of branding a place from a geographical point of view. They looked at how researchers conceptualized and measured the impact of place branding. Eletxigerraet al. (2018) offered to consider the traveler (or the client city) as the main co-creator of the value received from his/her experience of appointment (or the city). In this case, consumer resources, such as energy, mental mood, experience, or participation, could be crucial to explain the final assessment. Chan and Marafa (2018) explored the concept of branding in the modern competitive arena of places. They found multidimensional interpretations of places that offer a variety of opportunities to understand the true nature of destination branding better. Bastug et al. (2020) analyzed how port brands differ in different geographical regions and how each port's brand reveals seaport branding strategies. Cassinger et al. (2021) briefly reviewed the hallmark contributions that have shaped the branding of northern places and argued that the Scandinavian approach has now earned widespread international recognition. It outlined a hybrid scientific approach (Nordic wave) that combines management and critical branding schools and promotes more extroverted knowledge collaboration with branding practices. Hanna et al. (2021) presented a systematic overview of the place and destination branding, identified its main themes (general, brand identity, image and personality, politics, heritage, communications or media, country of origin, and design and infrastructure), and developed a conceptual map of the interaction between them. There are a lot of publications about the interconnection of business and territorial marketing where the object of the territory is one or a few countries (Bondarenko et al., 2020; Chygryn et al., 2019; Lyulyov et al., 2019). Of course, the interconnection between the territories' marketing and small and medium business should also be considered through the prism of the influence of environmental factors and events related to COVID-19 (Rahmanov et al., 2020; Starchenko et al., 2021).

At the same time, there are no publications on cooperation with government agencies, local people, investors and owners of local enterprises, small and medium-sized businesses, NGOs in developing the brand of the territory, the cooperation of cities for joint promotion (Bilan et al., 2019).

Methodology and research methods. Before the study, several hypotheses were put forward: 
1. Vectors of territorial marketing research have a close relationship with the concepts of politics, place marketing, tourism, model, place branding, region, and city. The economic benefits of implementing and marketing areas through the development of small and medium-sized businesses are becoming an increasingly important issue. They relate to policy and management in each specific area.

2. The issue of marketing territories is interesting every year for more and more scientists, and the geographical location of scientific schools should be ignored. It is more appropriate to focus on the study of research sponsorship, i.e., those stakeholders who may later become the owners of the research results.

3. There is a subjective statement that since the onset of quarantine measures, marketing areas are not relevant due to the high level of border closures and reduced traffic. Still, modern researchers now pay more attention to the inequity of cities, place identity, brand promotion.

This study begins with a systematic review of the literature to show existing knowledge about research in the marketing of territories and to identify gaps that provide opportunities for new research. 30 reviews of the literature on territory marketing were found.

A total of 1634 publications on the marketing of territories were chosen in the Web of Science database. After reviewing their titles, some of them were excluded as irrelevant. Further analysis was carried out based on 1611 publications.

The search was performed on the following key queries: place marketing OR place branding OR territorial marketing NOT marketplace (in the titles of publications).

At the first stage, the scientific literature on the marketing of territories was selected. Their titles were revised concerning the topic. Then, the titles of articles and journals, authors, the dates of publications, and the number of citations were analyzed. An analysis of citations of authors, publications, journals was conducted to identify more influential ones. The key indicator is the citation rate and the average citation rate for the year, which shows how the age of the article affects the level of citation.

Hierarchical cluster analysis was performed based on keywords. Visualization of topics of scientific literature was carried out using VOSviewer software tools. Future research topics were predicted based on the change of keywords over the analyzed period.

Results. The findings showed that more than 2,499 authors worldwide studied territorial marketing issues. At the same time, more than 20 authors have 10 or more publications on selected topics. Figure 2 visualizes the top-7 authors who published more than 14 papers.

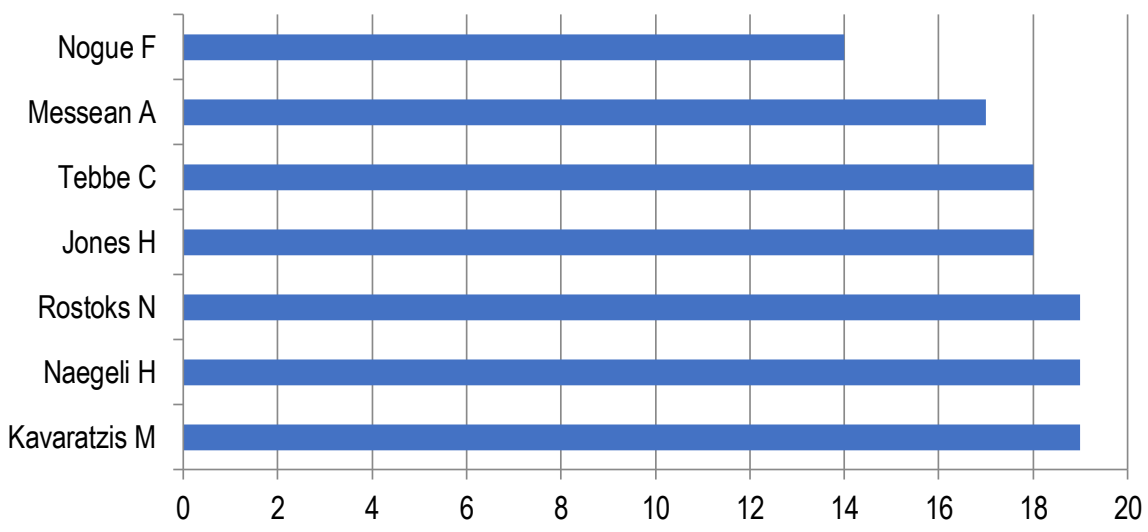

Figure 2. Top-7 authors published more than 14 papers on the marketing of territories Sources: developed by the authors based on the Web of Science database. 
Another 8 authors had 13 publications each, while 4 authors - 10-12 publications. Thus, it could indicate the impact of these data on research on the marketing of territories.

All studies have been published in more than 1000 scientific sources. Figure 3 shows the top-10 journals with the largest number of publications.

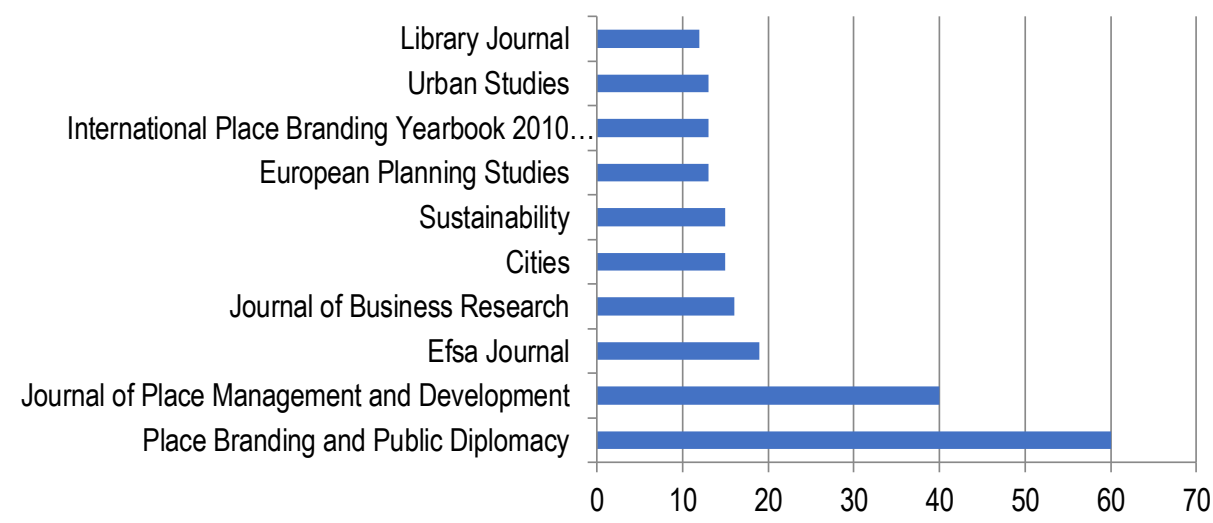

Figure 3. Top-10 scientific sources with the largest number of publications on the marketing of territories

Sources: developed by the authors based on the Web of Science database.

Figure 4 shows two scientific journals (Place Branding and Public Diplomacy and Journal of Place Management and Development) published 100 papers (6\% of the total). Other 8 journals published $12-19$ works. It may indicate the influence of these publications.

To confirm these hypotheses, the citations were analyzed and compared. All studies were cited 10103 times, an average of 8.5 citations per article, h-index is 44 . Table 1 presents the 10 most cited journals on the subject, with at least two publications on the selected topic.

Table 1. The most cited authors

\begin{tabular}{ccc}
\hline Author & Number of citations per author, pcs. & Number of cited articles, pcs. \\
\hline Kavaratzis M. & 561 & 19 \\
Braun E. & 463 & 8 \\
Warnaby G. & 359 & 10 \\
Zenker S. & 338 & 7 \\
Eshuis J. & 294 & 6 \\
Medway D. & 290 & 9 \\
Klijn E.-H. & 282 & 5 \\
Hatch M.J. & 277 & 2 \\
Kalandides A. & 193 & 3 \\
Halkier H. & 120 & 3 \\
\hline
\end{tabular}

Sources: developed by the authors based on the Web of Science database.

Comparison of Figure 2 and Table 1 showed that only Kavaratzis is in both lists. Warnaby G. also has 10 publications and a large citation rate. It indicates the influence of these authors on research on the marketing of territories. 
L., Khomenko, A., Rosokhata, A., Jasnikowski. Analysis of Territories Marketing Activities Among Small and Medium Business: A Bibliometric Analysis

Table 2 presents the 10 most cited publications about place marketing.

Table 2. Articles with the highest average citation rate

\begin{tabular}{ccccc}
\hline Author & Journal & Year & $\begin{array}{c}\text { Citations, } \\
\text { pcs. }\end{array}$ & $\begin{array}{c}\text { Average citation } \\
\text { rate, pcs. }\end{array}$ \\
\hline $\begin{array}{c}\text { Hosany S. et al. } \\
\text { Kavaratzis M \& Hatch } \\
\text { M.J. }\end{array}$ & Journal of Business Research & 2006 & 375 & 23.44 \\
van Ham P. & Marketing Theory & 2013 & 273 & 30.33 \\
Kavaratzis M. \& & $\begin{array}{c}\text { Annals of The American Academy of } \\
\text { Kallitical and Social Science }\end{array}$ & 2008 & 145 & 10.36 \\
$\begin{array}{c}\text { Kandides A. } \\
\text { Gibson C \& Davidson D. }\end{array}$ & Journal of Rural Studies & 2004 & 122 & 20.29 \\
$\begin{array}{c}\text { Selby M. \& Morgan N.J. } \\
\text { Zenker S. et al. }\end{array}$ & Tourism Management & 1996 & 113 & 6.78 \\
$\begin{array}{c}\text { Warnaby G. \& Medway } \\
\text { D. }\end{array}$ & Tourism Management & 2017 & 111 & 4.35 \\
Tsai S.P. & Marketing Theory & 2013 & 111 & 22.2 \\
Campelo A et al. & Journal of International Money and & 2012 & 109 & 12.33 \\
\hline
\end{tabular}

Sources: developed by the authors based on the Web of Science database.

According to Table 2, the first article was published in 1996 in the «Tourism Management» journal. The most cited article was published in the «Journal of Business Research» journal in 2006. The highest average citation rate is in the article published in the «Marketing Theory» journal in 2013. Comparison of Figure 3 and Table 2 shows that the «Journal of Business Research» is in both lists. Besides, the journals «Tourism Management» and «Marketing Theory» published the two most cited papers. It indicates the influence of these scientific journals. To understand modern research directions, a hierarchical cluster analysis of keywords was carried out (Figure 4).

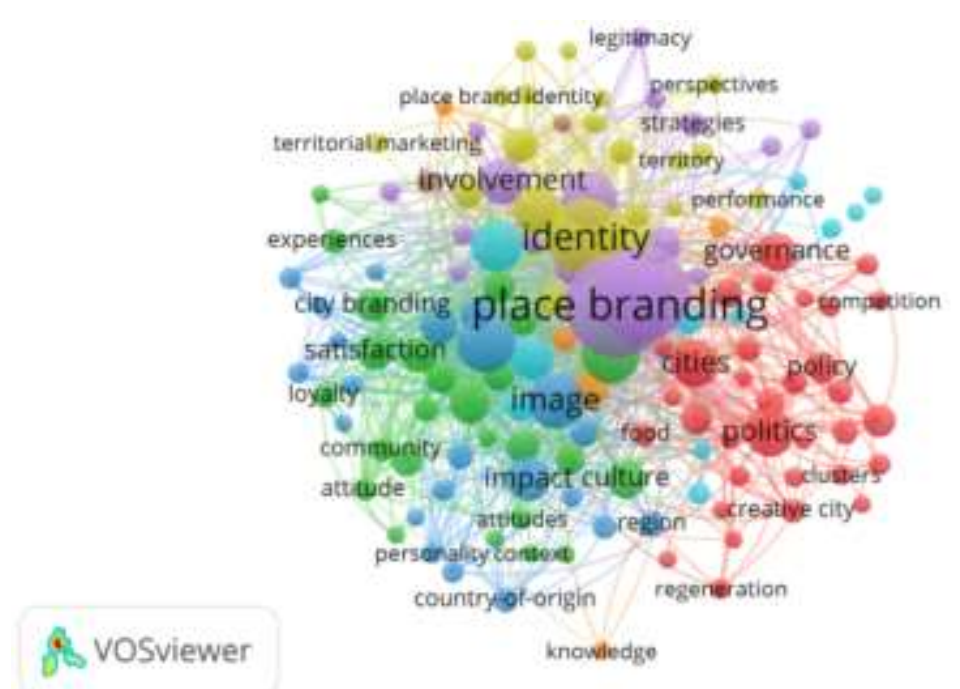

Figure 4. Clusters research devoted to the place marketing

Sources: developed by the authors based on the Web of Science database. 
Figure 5 shows eight clusters of research on the marketing of territories:

- Cluster 1 (red) - 34 items. Politics, 73 links, 161 total link strength.

- Cluster 2 (green) - 25 items. Tourism, 79 links, 172 total link strength.

- Cluster 3 (blue) -22 items. Model, 83 links, 240 total link strength.

- Cluster 4 (yellow) - 21 items. Identity, 105 links, 401 total link strength.

- Cluster 5 (purple) - 17 items. Place branding, 118 links, 589 total link strength.

- Cluster 6 (blue) - 11 items. Residents, 76 links, 221 total link strength.

- Cluster 7 (orange) -5 items. Framework, 48 links, 80 total link strength.

- Cluster 8 (brown) - 2 items. City brand, 24 links, 36 total link strength.

Therefore, most of the articles were devoted to the issues of place branding, identity, involvement, governance, image, impact culture, models, residents, place marketing, politics, satisfaction, city branding, etc. During 2018-2020, the directions of research changed rapidly. Figure 5 presents how research topics (based on keywords) have changed over the years.

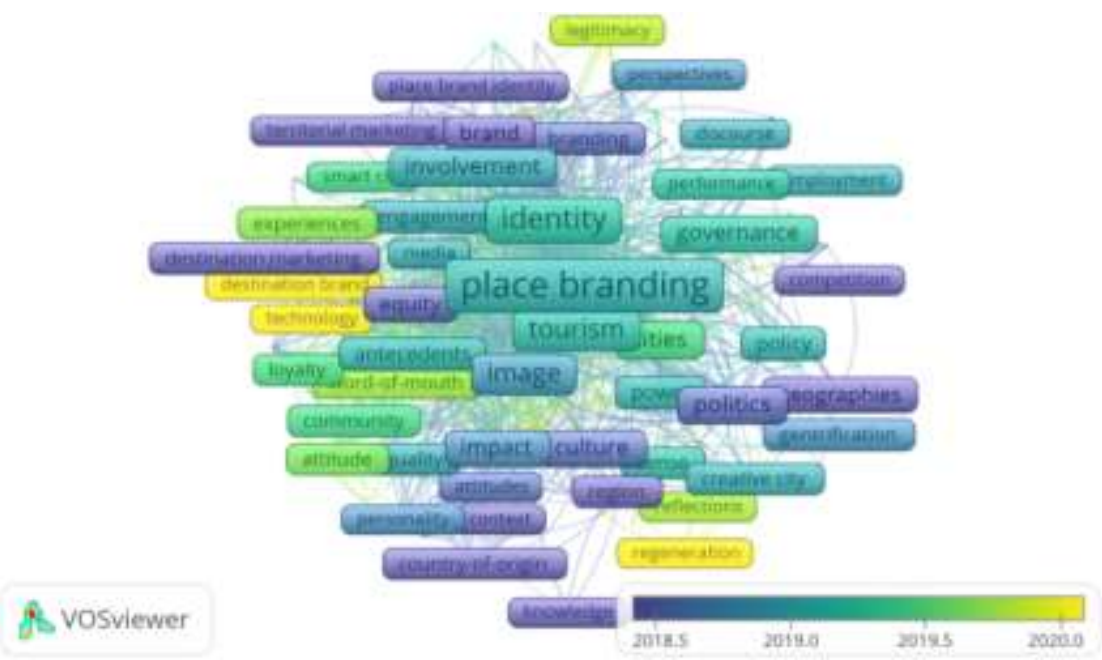

Figure 5. Dynamic of areas of research devoted to place marketing

Sources: developed by the authors based on the Web of Science database.

From 2018 to 2020, 488 articles were published, showing current research on place marketing. Figure 5 shows that in 2018, most research focused on place brands, destination marketing, geographies, politics, culture. In 2019, research was devoted mainly to place branding, identity, tourism, involvement, governance, impact, smart city, loyalty, community. In 2020 , most publications were devoted to destination brand, technology, regeneration, legitimacy, experiences, word-of-mouth, attitude, reflections. It indicates a deeper study of the topics.

In 2020-2021, studies focused on memory, inequity of cities, inclusive place branding, brand equity, place attachment, place identity, and others. Most likely, they will be further refined in the coming years.

To understand current and future areas of research, it is advisable to consider search queries on the Internet. Figure 6 shows the number of search queries for place marketing, place branding, territorial marketing, and related to them, such as city branding, city marketing. It reflects changes in users' requests to the marketing of territories over time. 


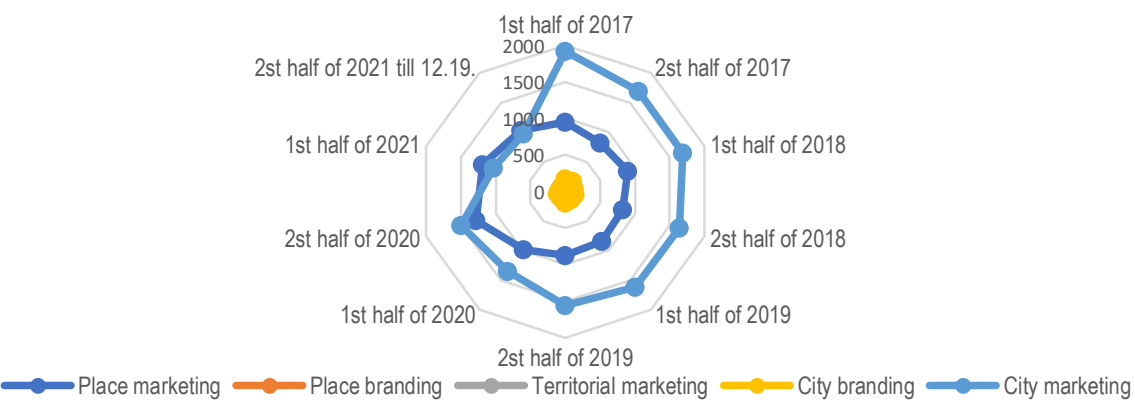

Figure 6. Map of Internet users' inquiries on the marketing of territories, 2017-2021

Sources: developed by the authors using the Google Trends tools.

Figure 6 shows that Internet users were most interested in city marketing and, to a lesser extent, in territorial marketing in general. Besides, the number of city marketing search requests decreased sharply, while place marketing increased during the COVID-19 pandemic. It could be caused by the importance of promoting not individual cities with a high density of people but entire complexes of territories. One can expect a trend of local tourism, such as green tourism, and the promotion of small remote areas.

Figure 7 shows the search for these queries differs in different regions. Thus, the residents of the Philippines, Morocco, Great Britain, Indonesia, and Australia are most interested in the issue of place marketing. Ethiopia, Nigeria, the Philippines, Ghana, and Kenya residents were also interested in place marketing. It could be due to awareness of the need for tourism development, identification of areas, etc. For many years, residents of Sweden, Australia, the United Kingdom, Canada, and the United States, countries with brand cities, were also most interested in place branding.

The issue of city branding is of interest to everyone, but most of all to residents of the Philippines, Pakistan, USA, South Africa, Britain, Malaysia. Thus, the residents of Indonesia, Canada, the United States, Great Britain, South Africa, and Italy were most interested in city branding (Table 3).

Table 3. The frequency of the queries «territorial marketing» in search engines by countries, 2017-2021

\begin{tabular}{cccccc}
\hline Country & \multicolumn{5}{c}{ Level of interest } \\
\cline { 2 - 6 } & $\begin{array}{c}\text { place } \\
\text { marketing }\end{array}$ & $\begin{array}{c}\text { place } \\
\text { branding }\end{array}$ & $\begin{array}{c}\text { territorial } \\
\text { marketing }\end{array}$ & $\begin{array}{c}\text { city } \\
\text { branding }\end{array}$ & $\begin{array}{c}\text { city } \\
\text { marketing }\end{array}$ \\
\hline $\mathbf{1}$ & $\mathbf{2}$ & $\mathbf{3}$ & $\mathbf{4}$ & $\mathbf{5}$ & $\mathbf{6}$ \\
\hline Philippines & 88 & 48 & 0 & 0 & 100 \\
Morocco & 22 & 0 & 100 & 9 & 0 \\
Great Britain & 18 & 60 & 0 & 28 & 16 \\
Indonesia & 9 & 0 & 0 & 100 & 7 \\
Australia & 18 & 75 & 0 & 0 & 11 \\
USA & 20 & 32 & 1 & 29 & 19 \\
Ethiopia & 100 & 0 & 0 & 0 & 0 \\
Canada & 17 & 39 & 0 & 31 & 13 \\
Sweden & 0 & 100 & 0 & 0 & 0 \\
South Africa & 40 & 0 & 0 & 28 & 18 \\
India & 26 & 27 & 0 & 9 & 9 \\
Malaysia & 35 & 0 & 0 & 0 & 15 \\
\hline
\end{tabular}


L., Khomenko, A., Rosokhata, A., Jasnikowski. Analysis of Territories Marketing Activities Among Small and Medium Business: A Bibliometric Analysis

\begin{tabular}{|c|c|c|c|c|c|}
\hline 1 & 2 & 3 & 4 & 5 & 6 \\
\hline Netherlands & 0 & 0 & 40 & 0 & 10 \\
\hline Nigeria & 48 & 0 & 0 & 0 & 0 \\
\hline Ghana & 47 & 0 & 0 & 0 & 0 \\
\hline Pakistan & 22 & 0 & 0 & 0 & 23 \\
\hline Kenya & 42 & 0 & 0 & 0 & 0 \\
\hline Ireland & 24 & 0 & 0 & 0 & 17 \\
\hline France & 11 & 0 & 21 & 7 & 2 \\
\hline Brazil & 17 & 18 & 0 & 0 & 1 \\
\hline New Zealand & 19 & 0 & 0 & 0 & 10 \\
\hline Italy & 4 & 0 & 0 & 20 & 2 \\
\hline Tanzania & 24 & 0 & 0 & 0 & 0 \\
\hline Vietnam & 7 & 0 & 0 & 0 & 8 \\
\hline Colombia & 6 & 0 & 0 & 0 & 3 \\
\hline Saudi Arabia & 4 & 0 & 0 & 0 & 4 \\
\hline Nigeria & 0 & 0 & 0 & 0 & 8 \\
\hline Thailand & 4 & 0 & 0 & 0 & 3 \\
\hline Republic of Korea & 6 & 0 & 0 & 0 & 0 \\
\hline Spain & 4 & 0 & 0 & 0 & 2 \\
\hline Mexico & 3 & 0 & 0 & 0 & 3 \\
\hline Germany & 2 & 0 & 0 & 0 & 4 \\
\hline Egypt & 0 & 0 & 0 & 0 & 5 \\
\hline Belgium & 0 & 0 & 0 & 0 & 4 \\
\hline Austria & 0 & 0 & 0 & 0 & 3 \\
\hline Argentina & 0 & 0 & 0 & 0 & 2 \\
\hline Turkey & 1 & 0 & 0 & 0 & 0 \\
\hline Poland & 0 & 0 & 0 & 0 & 1 \\
\hline Ukraine & 0 & 0 & 0 & 0 & 1 \\
\hline Russia & 0 & 0 & 0 & 0 & 1 \\
\hline Kazakhstan & 0 & 0 & 0 & 0 & 1 \\
\hline
\end{tabular}

Sources: developed by the authors.
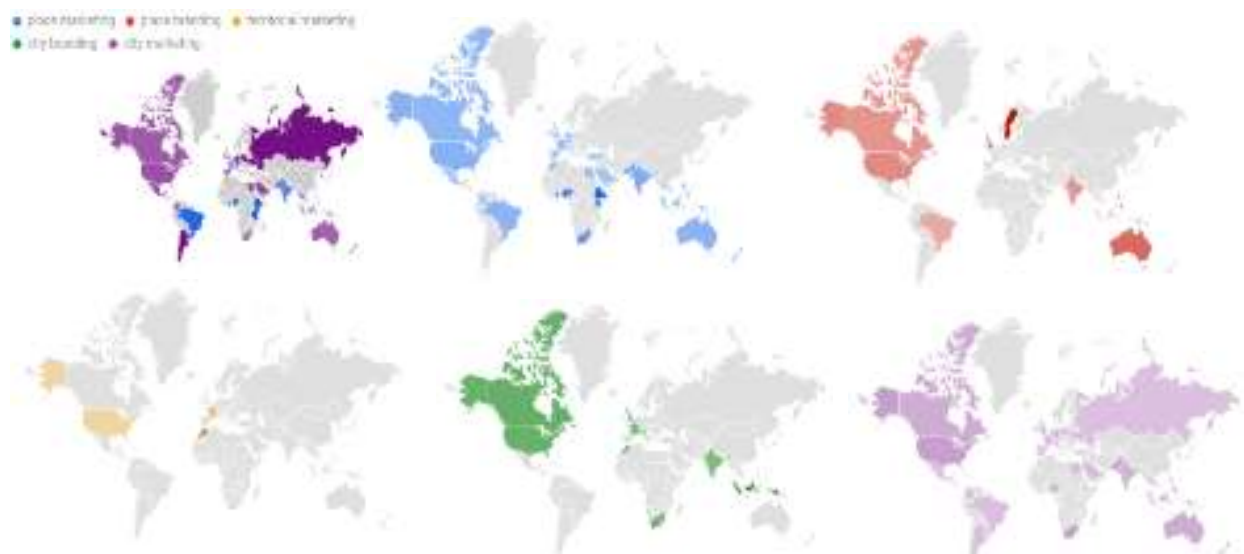

Figure 7. The intensity of the queries «territorial marketing» in search engines by countries, Sources: developed by the authors.

2017-2021 
In addition, using the service Google Books Ngram Viewer, the paper analyzed the trends in citations from 2010 to 2020 of the main phrases highlighted in this study (Fig. 8).

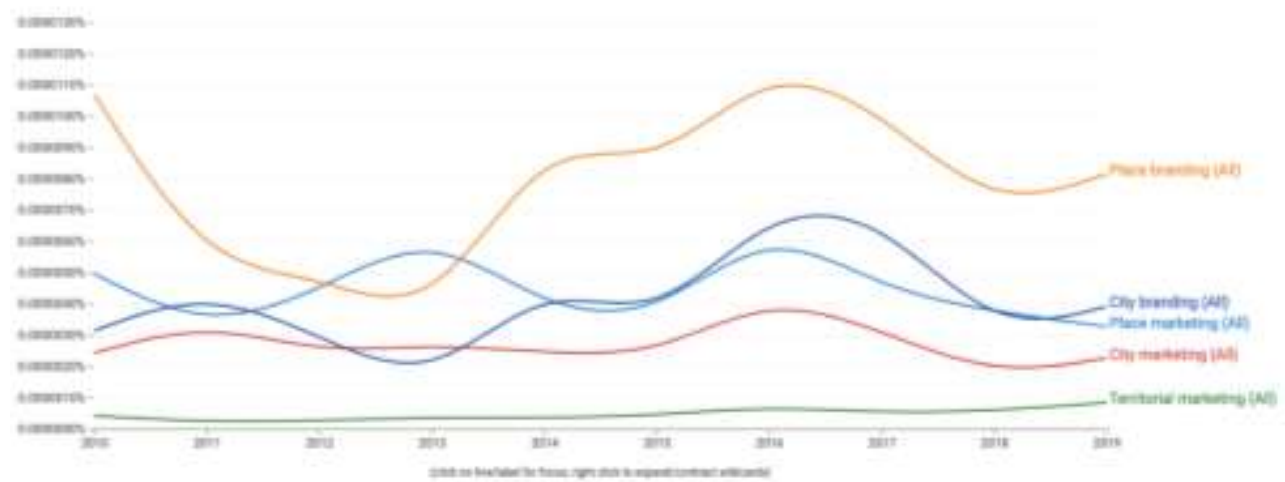

Figure 8. Dynamics in the citation of keywords for the query «territories marketing» in search engines (in English), 2010-2020

Sources: developed by the authors.

Figure 9 presents slightly different results from those of Google Trends. In this case, most citation in English was not for «city branding», but «place branding». Based on the keyphrase mentioning, "city branding» was in second place, while "place marketing» was third. Therefore, it indicates the greater publication interest in these phrases. In general, interest in all these statements actively increased in 2013 and has a general upward trend. However, it is necessary to analyze the full situation for 2020 and 2021 because of the COVID-19 impact. But overall, these studies make it clear that all of these key phrases go hand in hand, complementing and sometimes replacing each other. Therefore, in further research, none of them could be neglected.

Conclusions. This work aimed to understand the nature and features of existing research on the marketing of territories to determine the direction of future research for both scientists and practitioners. It is the first study to provide a comprehensive review of the literature on this issue. This study involved the trend analysis of the relevant literature published from 1970 to 2021. The citation analysis, hierarchical cluster analysis, and co-occurrence analysis by keywords in chronology were conducted. Four main conclusions were made. Initially, the influence of authors and articles on the marketing of territories was determined. The most popular journals were the Journal of Business Research, Tourism Management, and Marketing Theory. The most popular authors of the articles were Kavaratzis M. and Warnaby G. The findings showed that the researchers from the USA, England, Italy, Canada, the Netherlands, Germany, Australia, and France published most of the articles. Second, this study identified 8 key clusters in territory marketing through hierarchical cluster analysis: politics, tourism, model, identity, place branding, residents, framework, city brand. Third, this study analyzed key queries to articles in chronology. In the last 5 years, most research has focused on the issues of place brands, destination marketing, geographies, politics, culture, place branding, identity, tourism, involvement, governance, impact, smart city, loyalty, community.

Fourth, the directions of future research were evidenced by the topics of publications 2020-2021: destination brand, technology, regeneration, legitimacy, experiences, word-of-mouth, attitude, reflections, memory, inequity of cities, inclusive place branding, brand equity, place attachment, place identity, etc. It is advisable to emphasize the research on marketing of territories in further studies. At the same time, such issues as city-twinning, sister city, municipal cooperation are insufficiently researched. 
Understanding existing market gaps in research on the peculiarities of territorial development is very important for companies. It helps form management mechanisms for small and medium enterprises and their marketing activities. Unfortunately, the work retrieved only the data from the Web of Science database. This study includes no publications from the Scopus database.

The results could be helpful for companies that develop the brand of territories, local authorities for the development of place marketing, and scientists who research territorial marketing for the selection of journals, co-authors for publications, etc.

Author Contributions: conceptualization, A. R. and L. K.; methodology, A. R. and L. K.; software, L. K..; validation, L. K.; formal analysis, L. K. and A. R..; investigation, L. K, A. R., and A. J.; resources, L. K.; data curation, A. R.; writing-original draft preparation, L. K.; writing-review and editing, L. K., A. R.; visualization, L. K.; supervision, A. R..; project administration, A. R.; funding acquisition, A. J.

Funding: This research received no external funding.

\section{References}

Bastug, S., Sakar, G. D., \& Gülmez, S. (2020). An application of brand personality dimensions to container ports: A place branding perspective. Journal of Transport Geography, 82, 102552. [Google Scholar] [CrossRef]

Bilan, Y., Vasilyeva, T., Kryklii, O., \& Shilimbetova, G. (2019). The creative industry as a factor in the development of the economy: dissemination of European experience in the countries with economies in transition. Creativity Studies, 12(1), 75-101. [Google Scholar] [CrossRef]

Bondarenko, A. F., Syhyda, L. O., Saher, L. Y., \& Zakharkina, L. S. (2020). The economic and marketing attractiveness of countries: Measurement and positioning in terms of economic security. International Journal of Sustainable Development and Planning, 15(4), 439-449. [Google Scholar] [CrossRef]

Campelo, A., Aitken, R., \& Gnoth, J. (2014). Sense of Place: The Importance for Destination Branding. Journal of Travel Research, 53 (2) , pp.154-166. [CrossRef]

Cassinger, C., Gyimothy, S., \& Lucarelli, A. (2021). 20 Years of Nordic Place Branding Research: A Review and Future Research Agenda. Scandinavian Journal of Hospitality and Tourism, 21(1), 102-110. [Google Scholar] [CrossRef]

Chan, C. S., \& Marafa, L. M. (2018). Branding Places and Tourist Destinations: A Conceptualisation and Review. The Branding of Tourist Destinations: Theoretical and Empirical Insights, 15. [oogle Scholar] [CrossRef]

Chygryn, O., Pimonenko, T., Bilan, S., \& Starchenko, L. (2019). Digital marketing for green goods promotion: modern trends in entrepreneurship. The impact of Industry 4.0 on the level of shadow employment. International Scientific Conference on The Impact of Industry 4.0 on Job Creation Location: Trencianske Teplice, Slovakia Date: NOV 21, 2019, 160-166. [Google Scholar]

Cleave, E., \& Arku, G. (2017). Putting a number on place: a systematic review of place branding influence. Journal of place management and development, 10 (5), 425-446. [Google Scholar] [CrossRef]

Eletxigerra, A., Barrutia, J. M., \& Echebarria, C. (2018). Place marketing examined through a service-dominant logic lens: A review. Journal of Destination Marketing \& Management, 9, 72-84. [Google Scholar] [CrossRef]

Gibson, C., \& Davidson, D. (2004). Tamworth, Australia's 'country music capital': place marketing, rurality, and resident reactions. Journal of Rural Studies, 20(4), 387-404. [Google Scholar] [CrossRef]

Hanna, S., Rowley, J., \& Keegan, B. (2021). Place and destination branding: A review and conceptual mapping of the domain. European Management Review, 18(2), 105-117. [Google Scholar] [CrossRef]

Hosany, S., Ekinci, Y., \& Uysal, M. (2006). Destination image and destination personality: An application of branding theories to tourism places. Journal of business research, 59(5), 638-642. [Google Scholar] [CrossRef]

Kavaratzis, M., \& Hatch, M. J. (2013). The dynamics of place brands: An identity-based approach to place branding theory. Marketing Theory, 13(1), 69-86. [Google Scholar] [CrossRef]

Kavaratzis, M., \& Kalandides, A. (2015). Rethinking the place brand: the interactive formation of place brands and the role of participatory place branding. Environment and Planning A, 47(6), 1368-1382. [Google Scholar] [CrossRef]

Khomenko, L., Saher, L., \& Polcyn, J. (2020). Analysis of the marketing activities in the blood service: bibliometric analysis. Health Economics and Management Review, (1), 21. [Google Scholar] [CrossRef]

Khomenko, L. M. Saher, L. Y. \& Letunovska, N. Y. (2021). Segmentation as a base for digital marketing strategies in blood service: A cluster analysis for classifying healthy regional subjects. E3S Web of Conferences. [Google Scholar]

Kiralova, A. (1995). Marketing of the tourist place of destination. Economic casopis, 43 (6), 516-529.

Liubchak, V. V., Khomenko, L. M., Kovalishyn, M. P., Ilyina, V. V., Babar, T. V., Sikora, V. V., Simonova, O.,V. (2021). New Marketing Tools in the Blood Service to Optimize Quality Management. Wiadomości Lekarskie, 9(74), 2192-2196. [Google Scholar] Lyulyov, O., Pimonenko, T., Bilan, Yu., \& Lyeonov, S. (2019). Brand management and macroeconomic stability of the country. Polish Journal of Management Studies, 19 (2), 61-74. [CrossRef] 
L., Khomenko, A., Rosokhata, A., Jasnikowski. Analysis of Territories Marketing Activities Among Small and Medium Business: A Bibliometric Analysis

Madsen, H. (1992). Place-marketing in Liverpool: a review. International Journal of Urban and Regional Research, 16(4), 633640. [Google Scholar] [CrossRef]

Metaxas, T. (2009). Place marketing, strategic planning and competitiveness: The case of Malta. European Planning Studies, 17(9), 1357-1378. [Google Scholar] [CrossRef]

Metaxas, T., \& Deffner, A. (2015). Using Critical Path Analysis (Cpa) in Place Marketing Process: a Methodological Approach in the Case of Rostock, Germany. European Spatial Research and Policy, 22(1), 135-151. [Google Scholar]

Rahmanov, F., Aliyeva, R., Rosokhata, A., \& Letunovska, N. (2020). Tourism Management in Azerbaijan Under Sustainable Development: Impact of COVID-19. Marketing and Management of Innovations, 3, 195-207. [Google Scholarl [CrossRef]

Rosokhata, A., Minchenko, M., Khomenko, L., \& Chygryn, O. (2021). Renewable energy: a bibliometric analysis. In E3S Web of Conferences (Vol. 250, p. 03002). EDP Sciences. [Google Scholar] [CrossRef]

Selby, M., \& Nigel, J. Morgan. 1996. Reconstruing place image: A case study of its role in destination market research. Tourism Management, 17(4), 287-294. [Google Scholar] [CrossRef]

Starchenko, L., Lyeonov, S., Vasylieva, T., Pimonenko, T., \& Lyulyov, O. (2021). Environmental management and green brand for sustainable entrepreneurship. In E3S Web of Conferences(Vol. 234, p. 00015). EDP Sciences. [CrossRef]

Tsai, S. P. (2012). Place attachment and tourism marketing: Investigating international tourists in Singapore. International Journal of Tourism Research, 14(2), 139-152. [Google Scholar] [CrossRef]

Us, Y. O., Bilan, S., Pimonenko, T. V., Seliga, R., \& Ostasz, G. (2020). Green brand for sustainable business: bibliometric analysis. IBIMA Conference. [Google Scholar]

Van Ham, P. (2008). Place branding: The state of the art. The Annals of the American Academy of Political and Social Science, 616(1), 126-149. [Google Scholar] [CrossRef]

Warnaby, G., \& Medway, D. (2013). What about the 'place'in place marketing?. Marketing Theory, 13(3), 345-363. [Google Scholar] [CrossRef]

Zenker, S., Braun, E., \& Petersen, S. (2017). Branding the destination versus the place: The effects of brand complexity and identification for residents and visitors. Tourism Management, 58, 15-27. [Google Scholar] [CrossRef]

Лілія Хоменко, Сумський державний університет, Україна

Анна Росохата, к.е.н., Сумський державний університет, Україна

Адам Ясніковскі, директор фундації EUROWEEK, Польща

Аналіз маркетингової діяльності територій серед малого та середнього бізнесу: бібліометричний аналіз

Стаття узагальнює аргументи та контраргументи в рамках наукової дискусії щодо питань маркетингу територій. Головною метою дослідження є визначення майбутніх напрямків досліджень на основі аналізу сутності та особливостей наявних наукових публікацій, присвячених питанням маркетингу територій. Аналіз низки наукових публікацій з означено тематики засвідчив необхідність проведення синтезу наявних наукових напрацювань. Актуальність дослідження означено наукової проблеми полягає в існуванні низки невирішених проблем у маркетингу державного управління. Дослідження проведено в наступній логічній послідовності: визначено найбільш впливових авторів, журнали та статті в області маркетингу територій; проведено аналіз ключових слів досліджуваних статей, які було згруповано у кластери; здійснено візуалізацію наукових напрацювань, присвячених питанням маркетингу територій. Емпіричний аналіз базується на даних за 1970-2021 роки. Об'єктом дослідження є 1611 публікації, які було опубліковано у різних наукових виданнях. За результатами проведеного аналізу встановлено, що найвпливовішими журналами $є$ «Journal of Business Research», «Tourism Management» та «Marketing Theory». При цьому автори Каваратзіс М. та Варнабі Г. були найбільш продуктивними у дослідженні означеної тематики. Більшість статей було опубліковано дослідниками з США, Англії, Італії, Канади, Нідерландів, Німеччини, Австрії та Франції. За результатами бібліометричного аналізу, ключові слова досліджуваних статей згруповано у 8 кластерів (політика, туризм, модель, ідентифікація, брендинг місць, резиденти, рамки, бренди міст). Встановлено, що за останні 5 років, науковці найбільше досліджували брендинг місць, маркетинг туристичного призначення, політичні та культурні особливості, територіальні характеристики, туризм, ідентичність, залучення, уряд, розумні міста, лояльність, суспільство тощо. Отримані результати засвідчили, що перспективними напрямками майбутніх досліджень $є:$ туристичний бренд, технології, відновлення, легітимність, «сарафанне радіо», досвід, пам'ять, нерівність міст, інклюзивний брендинг міст, капітал бренду, прихильність до бренду, ідентичність міст тощо. До того, авторами рекомендовано зосередити увагу на дослідженні особливостей міст-побратимів та муніципальної кооперації. Результати дослідження мають практичне значення та можуть бути корисними для компаній, які розробляють бренд територій, органам місцевої влади при формуванні маркетингової стратегї̈ розвитку територій, а також науковцям, які досліджують маркетинг територій.

Ключові слова: бібліометричний аналіз, брендинг місць, малі та середні підприємства, маркетингове управління, маркетингові інструменти, маркетинг місць, територіальний маркетинг, туристична інфраструктура, партнерство для сталого розвитку, бренд міста. 